\title{
LEPRA PADA SISA RANGKA MANUSIA DARI LEWOLEBA: RELEVANSINYA TERHADAP SEJARAH PENGHUNIAN INDONESIA
}

\author{
Toetik Koesbardiati \\ (Departemen Antropologi FISIP, \\ Seksi Antropologi Ragawi Fakultas Kedokteran, \\ Lembaga Penyakit Tropis Universitas Airlangga) \\ Toetik koesbardiati@unair.ac.id
}

\begin{abstract}
ABSTRAK
Lepra adalah penyakit kronis pada manusia yang dapat menular. Penyakit ini menyerang kulit, membrane mukosa, saraf periperi, mata, tulang dan testis yang disebabkan oleh Mycobacerium leprae. Beberapa penelitian menunukkan bahwa sejarah manusia akhir-akhir ini, lepra telah tersebar di seluruh dunia. Oleh karena itu, sangat penting untuk meletakkan kasus lepra pada peta persebaran penyakit dalam rangka membangun pengetahuan yang lebih luas, tidak hanya berkenaan dengan persebaran penyakit itu sendiri melainkan juga untuk menganalisis persebaran manusia modem. Tujuan dari studi ini adalah untuk mendeteksi penyakit infeksi lepra pada popuasi kuno guna mengetahui relevansinya dengan sejarah penghunian di Indonesia. Penelitian ini menggunakan metode makroskopik berdasarkan metode dari Ortner dan Aufderheide \& Rodriguez-Martin untuk mengidentifikasi lepra pada cranium dari specimen LLI/5 dari Lewoleba, pulau Lembata. Antikuitas LLI/5 berdasarkan C14 adalah 2990 \pm 160 . Hasil pengamatan menunjukkan bahwa LLI/5 menderita lepra semasa hidupnya. Beberapa penelitian tentang penyakit infeksi, termasuk lepra, menyimpulkan bahwa kemunculan lepra berkaitan dengan migrasi manusia, dalam hal ini persebaran manusia modern. Beberapa penelitian telah membuktikan bahwa persebaran lepra konsisten dengan sumber manusia modern yaitu di Afrika Timur. Persebaran lepra juga sesuai dengan jalur persebaran manusia modem dari Afrika. Berdasarkan hal ini disimpulkan bahwa karena lepra tersebar sesuai dengan migrasi manusia, hal ini berarti bahwa lepra dapat menjangkiti populasi kuno di Indonesia. Hal ini disebabkan karena Indonesia adalah salah satu jalur migrasi persebaran manusia modem.
\end{abstract}

Kata kunci: Paleopatologi, Mycobacterium leprae, Lewoleba, sejarah penghunian Indonesia 


\title{
THE EVIDENCE OF LEPROSY IN HUMAN REMAINS FROM LEWOLEBA: THE RELEVANCE TO THE PEOPLING OF INDONESIA
}

\begin{abstract}
Leprosy is a chronic, mildly communicable disease of man which primarily affects the skin, mucous membranes, peripheral nerves, eyes, bones and testes due to Mycobacterium leprae. Some researches show the evidence of leprosy spread worldwide in recent human history. Therefore, it is important to put leprosy's case on the map to build broader knowledge, not only about the spread of leprosy, but also about human dispersal. The aim of the present study is to detect the M.leprae from ancient population in order to know its relevance to the peopling of Indonesia. Macroscopic method was performed based on Ortner method and Aufderheide and Rodriguez-Martin method to identify leprosy on the cranium of Lewoleba specimen (LLI/5), from Lembata Island, Indonesia. The antiquity of Lewoleba specimen is $2990+/-160 B P$. The results of the macroscopic method show that the specimen has suffered from leprosy in her lifetime. Some researchers concluded that emergence of leprosy related to human migration, in term of modern human dispersal, some researchers proved that the spread of leprosy worldwide consistent with the source of modern human (East Africa) and the spread of leprosy is also fit with the pattern of modem human dispersal. This fact provides an important clue how the $M$. leprae spread worldwide. Because the leprosy spread through human migration, this means also that leprosy could be infected the ancient people of Indonesia. This is because Indonesia was one of modern human migration's route.
\end{abstract}

Keywords; paleopathology,Mycobacterium leprae, Lewoleba, history of Indonesia settlement

\section{LATAR BELAKANG}

Lepra disebut juga Hansen's disease, yaitu penyakit infeksi pada manusia yang bersifat kronis, yang mempengaruhi kulit, jaringan hidung, syaraf tepi dan jaringan tulang. Penyebab penyakit ini adalah Mycobacterium leprae (Aufderheide dan Rodriguez-Martin, 1998). Lepra bekerja sangat lambat dengan masa inkubasi yang sangat lama (3-6 tahun) tapi berakibat sangat destruktif pada jaringan tubuh, yaitu terjadinya mutilasi tubuh. Infeksi ini dapat berupa bercak-bercak putih pada kulit yang mati rasa (Tuberculoid) dan akan berkembang hingga Lepromatous. Semakin parahnya tingkatan tipe lepra tidak hanya karena perkembangan penyakit itu sendiri, melainkan juga tergantung pada daya tahan tubuh (immune system). Lepromatous hingga pada tahap yang parah dapat terekam pada tulang. Infeksi pada tulang tertampak pada periostitis (infeksi pada daerah 
periosteum, yaitu bagian paling luar pada jaringan tulang), osteitis (infeksi pada korteks) dan osteomyelitis (infeksi pada bagian spongiosa dan sumsum tulang). Pada kasus lepra, infeksi tulang terletak pada wajah, tangan dan kaki hingga pada tahap tertentu terjadi mutilasi (Chhem \& Brothwell, 2008).

Dalam sejarah, timbulnya penyakit, lepra adalah salah satu penyakit infeksi pembunuh manusia yang utama. sekalipun saat ini lepra sudah dapat disembuhkan dengan antibiotic-antibiotik tertentu, namun masih banyak orang terjangkit lepra setiap tahunnya. Lingkungan adalah faktor penting yang mendukung perkembangan lepra. Saat ini penyebaran lepra lebih dominan di wilayah-wilayah dengan iklim yang panas lembab atau tropis. Sekalipun demikian lepra juga dapat berkembang di wilayah-wilayah dingin seperti Eropa. Pada abad 19 lepra banyak menyerang wilayahwilayah beriklim dingin dan menimbulkan banyak korban. Kemudiam pada masa-masa berikutnya lepra di Eropa mulai berkurang. Tampaknya hal ini berkaitan dengan perbaikan sanitasi, penataan rumah-rumah penduduk, perbaikan gizi dan sebagainya. Sebaliknya lepra terus menyerang wilayah negara-negara sedang berkembang yang umumnya masih buruk dalam sanitasi, kumuh, padat penduduk, kelas ekonomi rendah dan persoalanpersoalan kurang gizi, hygiene rendah, serta persoalan-persoalan lingkungan lainnya (Louisiana Office of Public Health, 2004).

Catatan atau laporan tentang lepra bersumber pada cerita-cerita dalam Perjanjian Lama di Alkitab di masa abad pertengahan dan juga catatan dari berbagai budaya di tempat yang berlainan. Laporan pertama kali berasal dari papyrus Mesir sekitar 1550 BC (Gwen et al., 2009). Lepra disebutkan pula dalam catatan kesehatan dari India berbahasa Sanskrit Atharva Veda pada 600 BC (Gwen et al., 2009; Ortner, 2003). Catatan kesehatan yang kemudian diterima sebagai sumber terpercaya adalah Sushruta Samhita dari Asia Selatan dan Arthasasthra pada 600 BC. Berturut-turut kemudian pada abad ke 4 dan ke 3 ditemukan catatan mengenai lepra dari Yunani dan China serta abad ke 1 dari masa Romawi (Gwen et al., 2009). Beberapa penelitian menunjukkan kekunoan penyakit lepra ini (lihat Tabel 1).

Tabel 1. deteksi $m$. leprae pada sampel-sampel arkeologis di beberapa tempat di dunia

\begin{tabular}{|l|l|l|l|l|}
\hline No & \multicolumn{1}{|c|}{ Situs } & Antikuitas & \multicolumn{1}{c|}{ Metode } & \multicolumn{1}{c|}{ Referensi } \\
\hline 1 & $\begin{array}{l}\text { SK 26, situs } \\
\text { Hatanai, Jepang }\end{array}$ & Ab. 18-19 & Makroskopik & $\begin{array}{l}\text { Suzuki, K. et al. } \\
2010\end{array}$ \\
\hline 2 & $\begin{array}{l}1997-1, \text { situs } \\
\text { Balathal, India }\end{array}$ & 2000 B.C. & Molekular & $\begin{array}{l}\text { Gwen, R. et al. } \\
2009\end{array}$ \\
\hline 3 & $\begin{array}{l}\text { R2208, R180, } \\
\text { situs Bavaria, } \\
\text { Jerman }\end{array}$ & Ab. 15-19 & Molekular & $\begin{array}{l}\text { Haas, J.C. et al. } \\
2000\end{array}$ \\
\hline
\end{tabular}




\begin{tabular}{|l|l|l|l|l|}
\hline 4 & $\begin{array}{l}\text { S237a, S237b, } \\
\text { S202, situs } \\
\text { Sarretudvari- } \\
\text { Hizofold, Hungaria }\end{array}$ & Ab. 10 & Molekular & $\begin{array}{l}\text { Haas, J.C. et al. } \\
2000\end{array}$ \\
\hline $\mathbf{5}$ & $\begin{array}{l}\text { New Ark bay, } \\
\text { Scottland }\end{array}$ & Ab. 13-14 & Molekular & $\begin{array}{l}\text { Taylor, M.G. et } \\
\text { al., 2002 }\end{array}$ \\
\hline $\mathbf{6}$ & $\begin{array}{l}\text { Noen U-Loke, } \\
\text { Thailand }\end{array}$ & $\begin{array}{l}2500-1700 \\
\text { BP }\end{array}$ & $\begin{array}{l}\text { Makroskopik } \\
\text { Mikroskopik } \\
\text { Radiologi }\end{array}$ & $\begin{array}{l}\text { Tayles \& } \\
\text { Buckley, 2004 }\end{array}$ \\
\hline
\end{tabular}

Lepra dianggap sebagai penyakit kutukan. Beberapa sumber menyebutkan bahwa karena lepra dianggap sebagai penyakit kutukan maka individu yang terjangkit lepra harus diasingkan. Lepra juga bermakna tidak suci', 'tercemar', dan 'kotor' (dalam Perjanjian Lama Alkitab). Oleh karena itu bangsa-bangsa di Timur Tengah pada masa lampau selalu mengasingkan bahkan membuang individu yang terjangkit lepra supaya tidak 'mencemari', 'mengotori'; dan membuat orang lain tidak suci. Stigma ini berlaku hingga masa sekarang, bahkan tidak hanya di Timur Tengah, melainkan di wilayah-wilayah lepra terjangkit, termasuk Indonesia. Stigma terhadap penderita lepra masih ada hingga sekarang namun karena tingkat pengetahuan masyarakat masa kini semakin tinggi, stigma ini 'berubah' bentuk. Tidak sebagai penyakit kutukan, tetapi penyakit yang memalukan, menjijikkan dan menakutkan. Dianggap menjijikkan karena orang yang terjangkit lepra mempunyai luka (borok) dan juga wajah yang aneh. MollerChristensen menyebutnya facies leprosa (Ortner, 2003). Menakutkan karena pada tahap tertentu lepra ini akan menyebabkan proses-proses mutilasi anggota tubuh dimulai dari hidung, tangan dan kaki. Dengan kata lain stigma tentang lepra sesungguhnya sama. Individu yang menderita lepra juga tetap dijauhi dan dijauhkan (diasingkan).

Perkembangan lepra menurut Gwen et al (2009) berdampingan dengan perkembangan kebudayaan. Perkembangan kebudayaan berkaitan dengan persebaran manusia, meningkatnya interaksi dan meningkatnya kepadatan penduduk. Beberapa hasil penelitian menyebutkan bahwa persebaran lepra berkaitan dengan kemampuan manusia berdagang dan berinteraksi dengan manusia lain dari tempat yang menjadi lintasan perdagangan atau migrasi (Monot et al., 2009; Gwen, et al., 2009). Hal ini memicu perubahan vektor penyakit sehingga sangat sulit untuk mendeteksi bagaimana $M$. leprae ini dapat ditularkan. Selain itu $M$. leprae dapat bertahan di tanah lembab hingga 46 hari dan di mukosa hidung hingga 9 hari (Louisiana Office of Public Health, 2004).

Berdasar pada teori Out of Africa, persebaran manusia modem diawali dari Afrika Timur (Stringer, 1992; Koesbardiati, 2000) yang kemudian (berdasar bukti arkeologis yaitu Mode 3 Industri lithik) tersebar sekitar 100.000 tahun yang lalu melalui jalur utara (Levant, Eropa dan kemudian seluruh Euroasia) dan jalur selatan (semenanjung Arab , India, Srilanka, Indonesia hingga Australia) (Foley dan Lahr, 1997). Teori ini 
diperkuat oleh bukti genetic (Cann et. al., 1987; Stoneking \& Cann, 1989) yang menyatakan bahwa Afrika adalah sumber dari gene pool manusia modem. Deteksi persebaran manusia modem berdasarkan penyakit (lepra) telah dilakukan oleh Monot et al. (2005). Hasil penelitian Monot et al. memberi bukti baru bahwa penyakit lepra berawal mula di Afrika Timur yang kemudian tersebar ke seluruh dunia melalui migrasi manusia. Penelitian ini menggunakan metode molekuler dengan menggunakan teknik Single Nucleotide Polymorphism (SNP). Lebih jauh, Monot et al. berhasil mengklasifikasikan tipe lepra. Terkait dengan model persebarannya, lepra mempunyai 4 tipe: persebaran lepra ke Afrika Barat (tipe 3) dibawa melalui jalur perdagangan, ekspansi atau kolonialisme oleh orang-orang Eropa atau Afrika Utara yang sudah terinfeksi lepra. Lepra kemudian dibawa ke Karibia dan berlanjut hingga Amerika Selatan (tipe 4) melalui perdagangan budak. Lepra juga banyak ditemukan di wilayah Asia hingga Pasifik (tipe 1). Sedangkan tipe 2 adalah tipe yang paling jarang ditemukan. Tipe ini hanya ditemukan di wilayah Ethiopia, Malawi, India bagian utara dan Kaledonia Baru.

Saat ini lepra dengan prevalensi tinggi masih banyak dijumpai di wilayah Asia Tenggara termasuk Thailand, Indonesia dan Philipina. Apakah hal ini berkaitan dengan pola migrasi manusia modern yang berawal dari Afrika Timur sekitar 100.000 tahun yang lalu? Hal ini sangat menarik untuk dikaji berdasarkan bukti-bukti kemunculan penyakit infeksi.

Tujuan penelitian ini adalah untuk menggambarkan sejarah penghunian di Indonesia purba berdasarkan persebaran penyakit infeksi. Selama ini munculnya penyakit infeksi masih jarang digunakan untuk mendeteksi persebaran manusia. Penyakit ini sangat bergantung pada host dan host penyakit lepra adalah manusia. Karena manusia terus bergerak mencari ruang maka persebaran penyakit-penyakit infeksi, dalam hal ini lepra, berkaitan dengan migrasi manusia.

\section{BAHAN DAN METODE}

Bahan penelitian ini adalah specimen LLI/5 dari Lewoleba, pulau Lembata, di Nusa Tenggara Timur. LLI/5 (lihat Gambar 2) adalah salah satu temuan kranium diantara lima temuan kranium lainnya yang digali oleh Pater Dr. Th. Verhoeven bersama Dr. Adi Sukadana (drg. Lie Goan Liong) di tahun 1961. Berdasarkan catatan Dr. Adi Sukadana, lokasi utama ditemukannya rangka-rangka Lewoleba ada di daerah pantai, di teluk Lewoleba, yaitu bagian barat pulau Lembata dan Gunung Api. Secara geologis wilayah teluk Lewoleba keadaanya belum begitu stabil. Hal ini dapat dijelaskan dari perubahan garis pantai dan pertumbuhan ganggang laut. Dari singkapan akibat guguran tebing pesisir dapat dikelompokkan beberapa lapisan:

(1) lapisan A, adalah lapisan yang teratas, dimana oleh penduduk dimanfaatkan sebagai ladang jika musim hujan tiba. Warna lapisan ini 
kehitam-hitaman dan terutama mengandung banyak akar rumput dan tumbuhan. Pada lapisan A ini juga ditemukan banyak pecahan tembikar purba berjenis sama dengan yang ditemukan pada lapisan $B$.

(2) lapisan B berwama kemerah-merahan. Pada lapisan B ini digali situs LLI.

(3) lapisan C adalah lapisan peralihan antara lapisan B dan lapisan D. Sifat lapisan ini agak keras, seperti padas dan wamanya coklat kelabu.

(4) lapisan $D$ merupakan sedimen pasir yang telah membatu yang relatif homogen kekerasannya. Matrix D merupakan matrix utama dari semua penemuan sisa manusia subfosil di teluk Lewoleba.

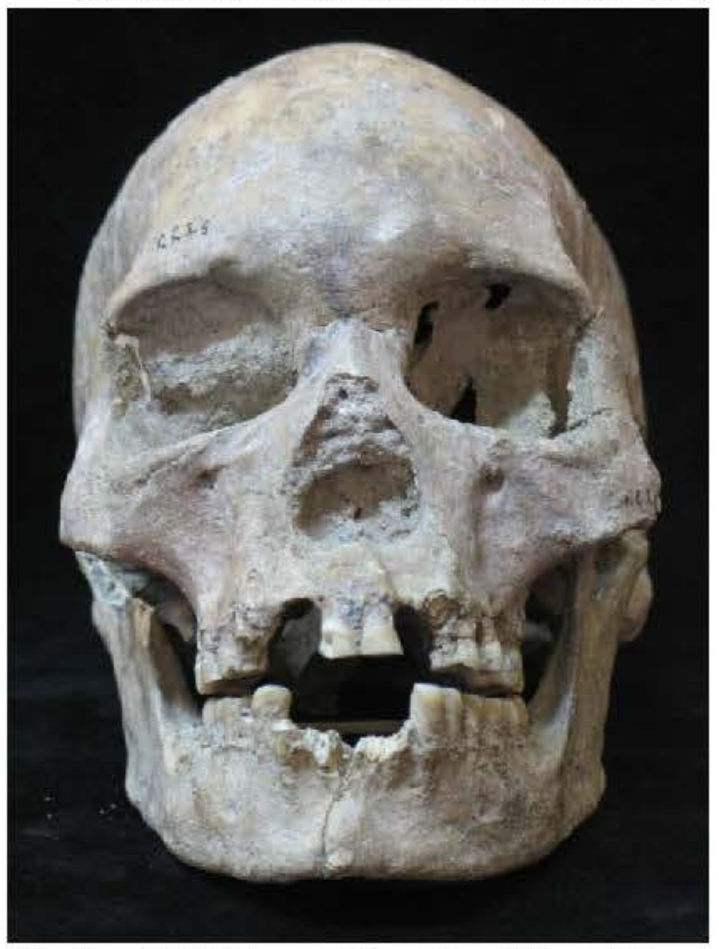

Gambar 1. LII/5 yang diternikan di Lewoleba, Pulau Lembata, Nusa Tenggara Timur (Foto: D.B. Murti)

Sisa rangka Lewoleba ditemukan di kedalaman $1.80 \mathrm{~m}$. Selain sisa rangka manusia ditemukan pula sisa makanan berupa tulang-tulang hewan, kulit-kulit lokan dan di samping itu juga ditemukan pecahanpecahan gerabah. LLI/5 terletak di sebelah selatan rangka LLI/4 dan LLI/3. Posisi LLI/5 sama dengan posisi rangka lainnya yaitu membujur ke arah SelatanUtara, dengan kepala di Selatan. LLI/5 hampir semua bagian dapat dikeluarkan dari matrixnya.

Antikuitas LLI/5 adalah akhir Neolitik, awal Paleometalik (Lie, 1964). Dengan penanggalan absolut berdasar C14 diperoleh angka $2990 \pm 160 \mathrm{BP}$ (Atmosudiro, 1994). Dalam penelitian ini hanya diobservasi sisa rangka LLI/5 yang diduga menderita lepra. Di samping itu, hanya bagian kranium yang dapat diidentifikasi mengingat setelah $\mathrm{Dr}$. Adi Sukadana meninggal dunia, koleksi-koleksi Flores ini kurang mendapat perhatian sehingga berpengaruh terhadap kelengkapan sisa rangka.

Untuk mendapatkan gambaran lengkap mengenai dugaan adanya lepra pada specimen Lewoleba digunakan metode makroskopik berdasarkan Ortner (2003) dan Aufderheide dan Rodriguez-Martin (1998). Ortner dan Aufderheide dan Rodriguez-Martin menjelaskan bahwa timbulnya lepra ditandai oleh adanya perubahan pada tulang. Perubahan tulang ini dapat bersifat tunggal maupun dalam bentuk kombinasi. Umumnya perubahan-perubahan pada tulang dapat ditemukan pada rongga 
nasal (nasal cavity), procesus alveolaris (alveolar process), dan permukaan rongga mulut. Perubahan tulang pada bagian-bagian ini bersifat infeksi dan merusak. Infeksi ini tidak mempengaruhi bagian mandibula (Aufderheide \& Rodriguez-Martin, 1998). secara detail Ortner dan Auderheide dan Rodriguez-Martin menjelaskan bahwa perubahan-perubahan pada tulang meliputi:

(1) Procesus alveolaris pada maksilla

Pada tahap awal terjadi resorpsi pada prostion berlanjut pada bagian anterior dan posterior dinding gigi seri, hingga menyebabkan longgamya gigi seri atas (makslila) dan lepasnya gigi seri tersebut. Moller-Christensen menyebutnya 'paradentosis leprosa' untuk membedakan dengan gangguan periodontal lainnya.

(2) Spina nasalis anterior

Atropi pada bagian spina nasalis anterior dapat terlihat baik pada rangka manusia maupun pada manusia hidup yang menderita lepra. Pada tahap awal terjadi resorpsi pada bagian ini hingga bentuk spina tidak beraturan. Tahap ini berkembang hingga spina nasalis betul-betul teresorpsi (hilang).

(3) Pinggiran apertura piriformis

Secara perlahan pinggiran apertura piriformis mengalami resorpsi secara bilateral dan simetris. Tahap berikutnya adalah terjadi proses remodeling awal pada pinggiran apertura piriformis. Pinggiran apertura menjadi bentuk tidak beraturan tapi akhirnya akan tertutupi dengan cortical bone.

(4) Procesus palatinus pada maksilla

Pola tertentu muncul pada bagian tengah permukaan nasal. Pada tahap awal muncul tonjolan halus yang kemudian berkembang menjadi lebih jelas. Pada tahap berikutnya tonjolan semakin jelas, berbentuk lingkaran konsentrik yang dapat muncul tunggal atau banyak. Perubahan awal timbulnya tonjolan palatinus pada permukaan rongga mulut terdapat di sepanjang sutura palatina. Pada tahap yang lebih parah muncul perforasi pada permukaan palatum.

(5) Struktur internasalis

Pada penderita lepra, struktur internasal sudah terjadi absorpsi total, terutama bagian septum. Pada sisa rangka, rusaknya struktur intranasal dan adanya remodeling pada pinggiran apertura piriformis memberi bentuk rongga hidung yang lebar dan kosong.

\section{HASIL DAN DISKUSI}

Observasi terhadap spesimen LLI/5 menunjukkan bahwa LLI/5 mengalami perubahan pada procesus alveolaris maksilla (Gambar 2). Resorpsi awal sudah mulai terjadi. Sekalipun agak tersamar karena proses tafonomi dan efek dari mutilasi kedua gigi seri lateral, resorpsi pada maksilla sudah terjadi dan berkembang secara progresif. Resorpsi yang aktif pada 
rongga hidung (apertura piriformis) telah mempengaruhi bagian alveolar sehingga berakibat pada tanggalnya caninus kanan maksilla. Kondisi ini diperkuat dengan adanya atropi pada spina nasalis anterior (lihat Gambar 3). Atropi pada spina nasalis anterior sangat jelas tampak jika dipandang dari sisi lateral. Sisi lateral juga memberi gambaran jelas resorpsi pada procesus alveolaris maksilla.

Resorpsi tahap awal juga ditemukan pada pinggiran apertura piriformis (lihat Gambar 4). Penumpulan pinggiran rongga hidung ini dapat dilihat dimulai pada margin bawah pinggiran apertura piriformis. Untuk lebih jelasnya, palpasi pada daerah pinggiran ini semakin memperkuat observasi adanya proses resorpsi.

Perubahan pada daerah palatum juga tampak dengan timbulnya tonjolan halus di sepanjang sutura palatina (lihat Gambar 5). Perforasi belum tampak jelas namun sudah mulai berproses. Struktur internasalis tidak tampak jelas karena rongga hidung pada spesimen LLI/5 dipenuhi dengan matrix yang susah di bersihkan (lihat Gambar 6). Secara umum bentuk apertura piriformis menjadi lebar dan kosong.

Berdasarkan hasil observasi tersebut di atas menunjukkan bahwa spesimen LLI/5 positif menderita lepra. Hasil observasi berdasarkan metode makroskopik ini diperkuat oleh penelitian dengan metode molekuler terhadap spesimen LLI/5 yang baru-baru ini dilakukan dan menunjukkan hasil positif terinfeksi $M$. leprae (Adriaty, et al., 2011)

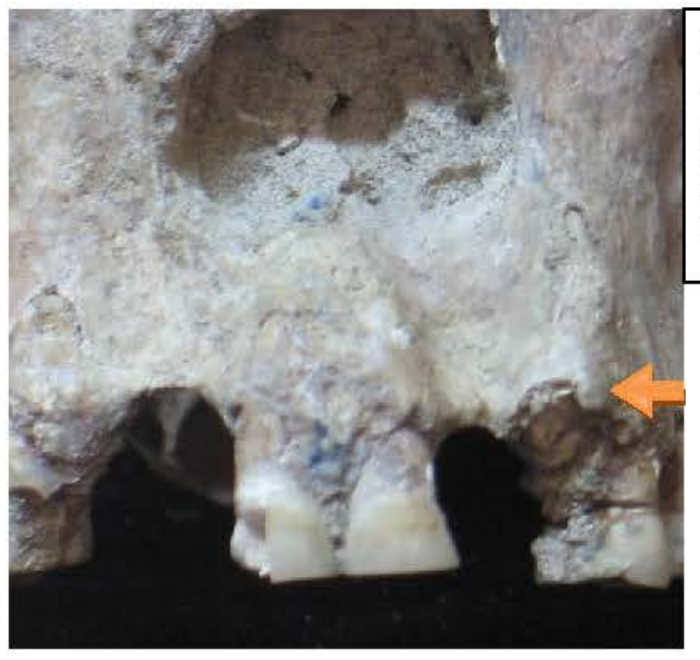

Gambar 2. Resorpsi pada procesus alveolaris pada maksilla Resorpsi awal sudah tampak sehingga (jika tidak karena mutilasi dentisi) akan berpengaruh terhadap lepasnya gigisigi depan (Foto: D. B. Murti) 


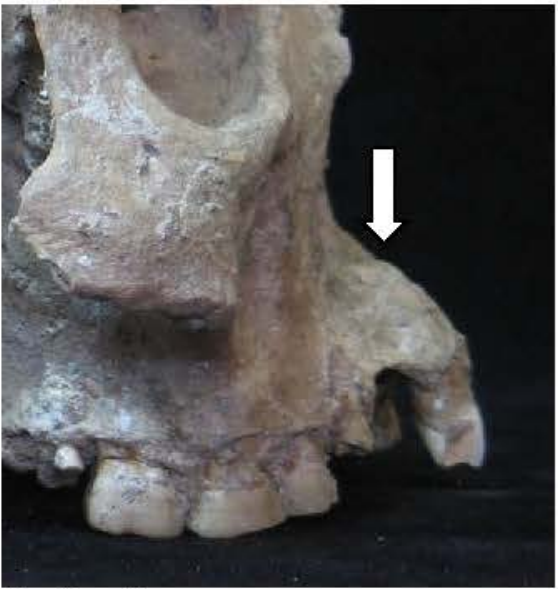

Gambar 3.

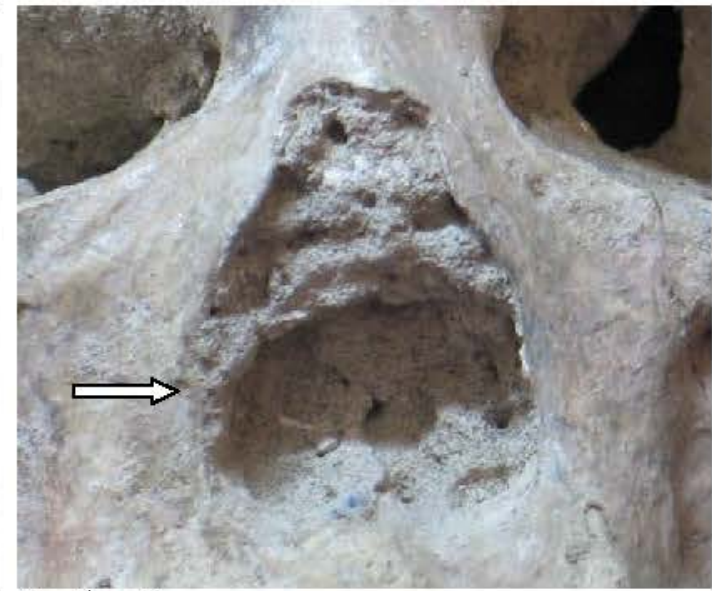

Gambar 4

Gambar 3. Spina nasalis dari sisi lateral tampak sudah terresorpsi

Gambar 4. Bagian apertura piriformis yang terkena resorpsi Bagian margin lateral menunjulkkan tumpulnya pinggiran mengindikasikan proses resorpsi yang aktif (Fots: D.B.Mirti)

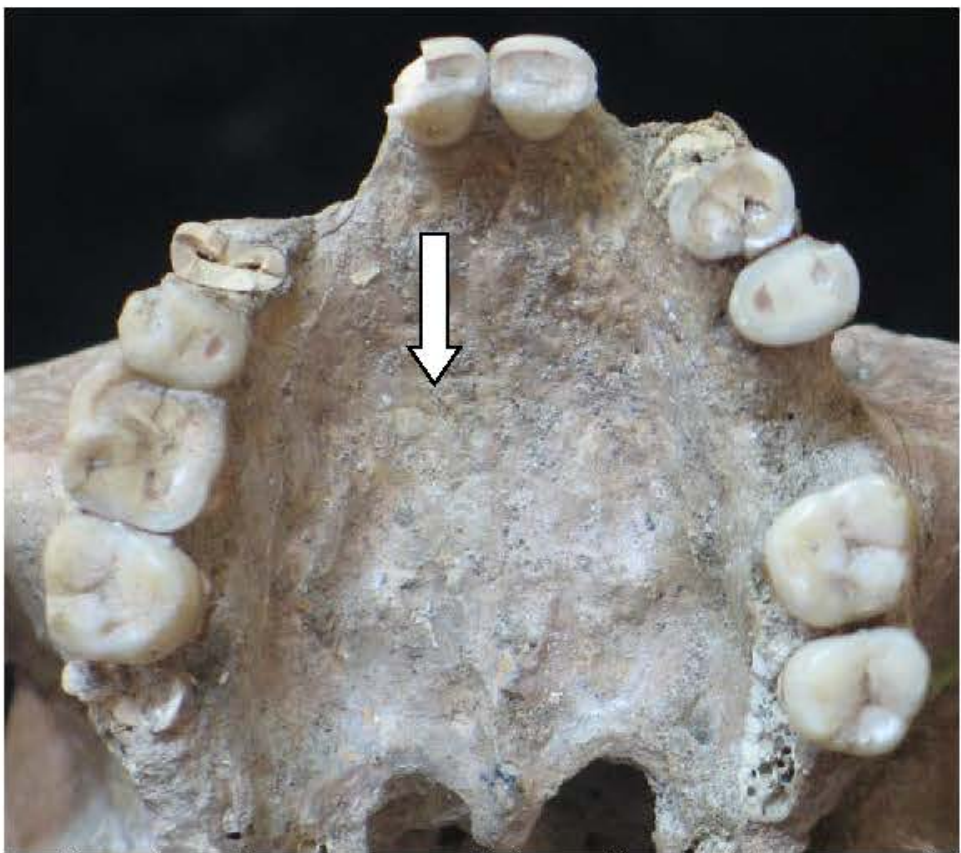

Gambar 5. Bagian prosesus palatinus dimana beberapa tonjolan akan mumet dan kermudian berkembang perforasi sebagai tanda $M$ lepree sedang aktif Pada LLJ/5 behum menuryjukkan tonjolon atau perforasi pada prosesus palatinus. (Foto: D.B. Murti) 


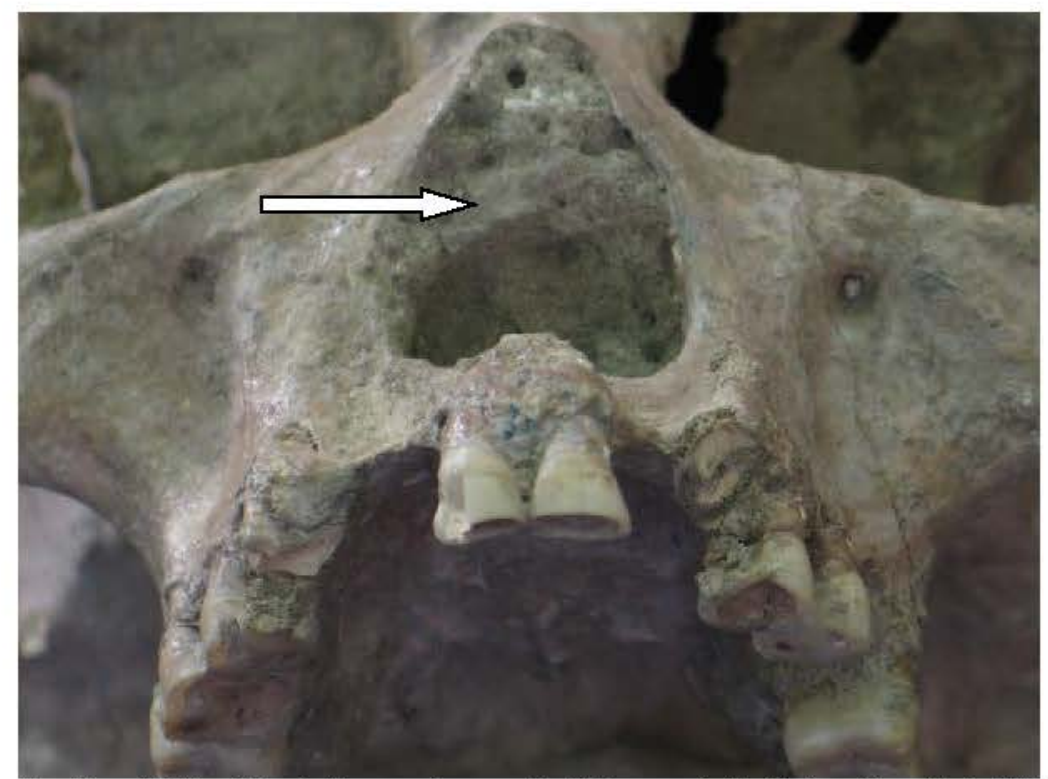

Gambar 6. Struktur internasal yang tertutup matrik. Dalam kondisi $M$ leprae aktif, nasal cavity akan kosong dan lebar. (Foto: D.B. Murti)

\section{PENGHUNIAN LEWOLEBA PURBA}

Bukti geologis saat dilakukan ekskavasi mengindikasikan bahwa Lewoleba pernah mengalami bencana yang kemudian memusnahkan seluruh penduduk di wilayah tersebut. Berdasarkan analisis gerabah yang ditemukan memberi informasi bahwa gerabah Lewoleba mempunyai pola hias yang sama dengan gerabah dari Melolo yaitu dengan pola hias geometris dan pola kedok (topeng) (Lie, 1964; 1965; Atmosudiro, 1994). Pola ragam hias seperti ini sudah dikenal luas di seluruh Indonesia pada jaman peralihan dari Neolitikum ke jaman logam (Lie, 1964).

Perbandingan terhadap jenis-jenis gerabah yang digunakan masyarakat Lewoleba moderen mengindikasikan bahwa gerabah moderen kurang berkualitas dan dengan pola ragam hias yang polos saja. Gerabahgerabah yang digunakan penduduk saat ini lebih banyak didatangkan dari pulau-pulau sekitar Lembata, misalnya Adonara. Jika penduduk saat ini menggunakan gerabah polos yang didatangkan dari tempat lain, bisa jadi bahwa penduduk purba juga tidak memproduksinya sendiri di Lewoleba (berkaitan dengan gerabah yang lebih berkualitas dengan pola hias).

Lie menyimpulkan bahwa penduduk Lewoleba purba merupakan kelompok penghuni yang kecil secara kuantitatif dan bersifat semi-stationer. Hal ini didasarkan pada jumlah temuan pecahan gerabah yang hanya sedikit dan berdasarkan sisa makanan yang tidak banyak. Kelompok penghuni ini menempati wilayah-wilayah pantai dalam waktu yang tidak lama. Penghunian di tempat ini juga terjadi berulang-ulang yang diduga hingga masa sejarah. Hal ini mengindikasikan bahwa kelompok-kelompok 
penghuni mempunyai relasi yang baik dengan penduduk di sekitar Lembata. Hal ini juga didukung oleh letak geografis Pulau Lembata yang berdekatan dengan pulau-pulau kecil lainnya di wilayah perairan Flores.

Pernyataan bahwa penduduk Lembata mempunyai relasi baik dengan wilayah-wilayah lain, diperkuat dengan tradisi mutilasi gigi yang ditemukan pada sisa-sisa rangka dari Lewoleba. Tradisi mutilasi gigi yang ditemukan di Lewoleba adalah pencabutan gigi seri lateral pada maksilla (lihat gambar 7). Tradisi ini juga ditemukan pada sisa rangka dari Liang Bua dan Melolo. Jika dikelompokkan menurut kesamaan mutilasi maka Lewoleba, Liang Bua dan Melolo ada dalam satu kelompok. Kelompok lain di kawasan Nusa Tenggara Timur yang mempunyai pola mutilasi lain adalah kelompok Liang Toge yaitu dengan pola pengerokan bagian labial gigi depan (Koesbardiati, T. \& Suriyanto, A., 2007b). Kesamaan pola mutilasi gigi ini diduga sebagai akibat dari relasi antar kelompok penghuni.

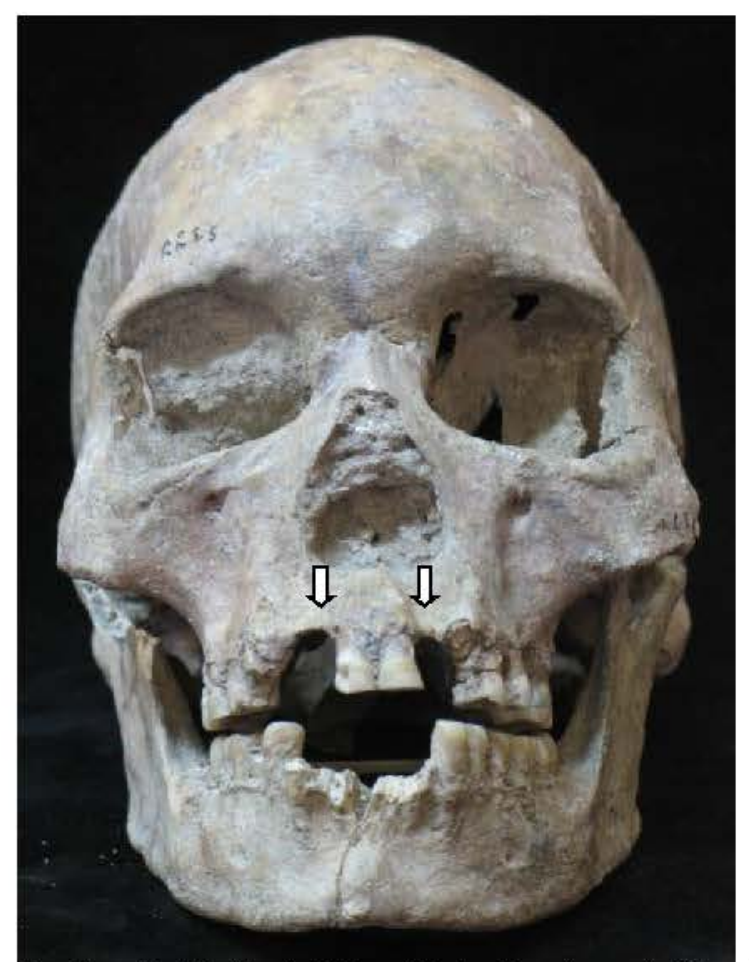

Gambar 7. Mutilasi gigi seri lateral pada maksilla sebagai tradisi yang dilakukan di senwua termuan sisa ranglka Lewoleba. Tradisi ini juga dikenal di Liang Bua dan Melolo. (Foto: D.B. Murti) 


\section{CATATAN ETNOGRAFI TERKAIT PREVALENSI LEPRA PENDUDUK PULAU LEMBATA SAAT INI}

Lepra tampaknya bukan penyakit baru di wilayah Lewoleba. Seorang pastor Katolik senior (Pater Jan) yang bertugas di wilayah Lewoleba menyatakan bahwa sejak beliau masih kecil (lahir tahun 1934) sudah banyak ditemui penderita Lepra di sana. Ironinya, banyak orang yang tidak tahu kalau sedang menderita lepra. Hal ini diindikasikan dari penduduk dengan cirri tuberculoid, bagian-bagian permukaan tubuh yang mati rasa. Penduduk yang sudah teridentifikasi sebagai penderita lepra ini begitu dikucilkan oleh masyarakat setempat. Banyaknya penderita lepra ini sempat menarik perhatian seorang Uskup di Larantuka (Uskup Mgr Theiyssen) untuk membantu para penderita. Beliau mengirim dua orang suster yang sebelumnya telah dididik di Wuerzburg, Jerman untuk menangani penderita lepra di Lewoleba. Dengan semangat yang tinggi dua suster ini mendatangi desa ke desa untuk mencari penduduk yang menderita lepra dan mengobatinya di tempat. Penduduk desa mengenali kehadiran dua suster ini sebagai mama hitam dan mama putih. Sebutan ini berdasar pada warna kulit para suster tersebut. Sebutan mama hitam adalah untuk suster Isabela yang berasal dari Larantuka dan mama putih adalah sebutan untuk suster Gisella yang berasal dari Wuerzburg, Jerman, sehingga sebutan ini sama sekali tidak bertujuan rasis.

Pada masa pendudukan Belanda waktu itu, pemerintah Belanda ikut mengatur menangani penderita lepra dari masyarakat desa. Pemerintah Belanda menempatkan para penderita lepra di Tanjung Naga, dimana para penderita mengurus sendiri hidup mereka bahkan hingga proses pemakaman penderita yang meninggal. Di Tanjung Naga bukan hanya penduduk Lewoleba sendiri yang terkonsentrasi di sana melainkan juga banyak penderita dari daerah-daerah lain sekitar Lewoleba seperti Manggarai, Adonara, Alor, Solor, Larantuka, Lamalera dll. Kondisi penanganan penderita memang masih terbatas waktu itu sehingga terkesan tidak nyaman karena lingkungan yang kurang sehat. hingga kemudian di tahun 1970-an paroki di Lewoleba dibantu oleh sebuah paroki dari Wuerzburg, Jerman membangun sebuah rumah sakit khusus untuk penderita lepra. Pembangunan rumah sakit ini dipimpin oleh pater Jan yang hingga saat ini bertugas sebagai imam paroki di Lewoleba. Sejak rumah sakit ini dioperasikan, penderita lepra mulai dialihkan dari Tanjung Naga untuk kemudian dirawat di rumah sakit tersebut hingga perlahan jumlah penderita lepra berkurang.

Stigma lepra di Lewoleba tidak jauh berbeda dengan di tempat lain. Lepra adalah penyakit yang dianggap sebagai penyakit kutukan sehingga penderita harus disingkirkan, dijauhkan dari masyarakat yang sehat. Berdasarkan keterangan dari Pater Jan, banyak penderita yang kemudian berobat ke rumah sakit di Lewoleba.

Jika hal ini terjadi sejak lama, terbukti dari LLI/5 yang terinfeksi lepra, maka dapat disimpulkan bahwa Lewoleba barangkali juga sejak lama sudah 
menjadi tempat tujuan penduduk sekitar Pulau Lembata. Kenyataan ini sesuai dengan deskripsi pendudukan purba yang dikemukakan oleh Lie (1964; 1965).

\section{LEPRA DAN SIGINIFIKANSINYA DENGAN MIGRASI INDONESIA PURBA}

Saat ini jumlah penderita lepra di Indonesia semakin berkurang. Tetapi hal ini bukan berarti bahwa penderita lepra tidak banyak. Beberapa kantong penderita lepra telah berhasil dideteksi melalui penelitianpenelitian. Di Jawa beberapa kantong yang terkenal adalah Mojokerto, Kediri, Lamongan (Ganif, 2011, komunikasi personal) dan Madura (Adriaty, et al., 2010). Selain itu di wilayah Indonesia bagian tengah juga ditemukan kantong-kantong penderita lepra misalnya di Maluku (Matsuoka, et al., 2004). Berdasarkan penjelasan etnografi di atas menunjukkan bahwa pulau Lembata adalah kantong penderita lepra di wilayah Indonesia bagian timur. Jika keberadaan wilayah endemic lepra (Indonesia bagian barat, tengah dan timur) dikaitkan dengan pola migrasi Indonesia purba, maka hal ini adalah bukti baru dalam menjelaskan penghunian Indonesia purba. Dengan ditemukannya bukti adanya $M$. leprae pada specimen LLI/5 memberi petunjuk baru bahwa lepra sudah ada di Indonesia sejak masa prasejarah.

Hipotesis mengenai penghunian di Indonesia telah disampaikan beberapa ahli, misalnya Jacob (1967) yang menjelaskan migrasi di Indonesia berdasarkan temuan-temuan sisa rangka prasejarah. Sebaliknya Glinka (1978) menjelaskan persoalan pola migrasi di Indonesia berdasarkan manusia hidup. Koesbardiati dan Suriyanto (2007a,b, 2010) menelusuri pola migrasi di Indonesia berdasarkan perlakuan budaya (mutilasi gigi). Hasil analisis pola migrasi Indonesia purba baik berdasar sisa rangka, manusia hidup maupun berdasarkan budaya mengindikasikan bahwa migran yang masuk ke Indonesia pada masa purba berawal dari arah Barat yang bergerak menuju ke Timur. Para migran ini terus mendesak kelompokkelompok penghuni hingga sampai ke Timur Indonesia. Kelompok migrant yang lain adalah mereka yang masuk Indonesia melalui wilayah Utara Indonesia dan bergerak ke Selatan ke wilayah Nusa Tengara Timur dan sekitarnya. Harus kita perhatikan di sini bahwa kelompok-kelompok migran (Mongoloid) masuk wilayah Indonesia secara berulang sehingga intensitas percampuran (admixture) dan akulturasi dengan penduduk sebelumnya (Australomelanesoid) dapat berpengaruh hingga tataran budaya.

Adanya akulturasi terekam dalam ciri-ciri morfologi yang menunjukkan derajat percampuran antara elemen rasial Mongoloid dan Australomelanesoid. Percampuran-percampuran ini terutama tampak pada temuan sisa-sisa rangka dari wilayah Nusa Tenggara Timur (Koesbardiati \& Suriyanto, 2007a,b; Lie, 1965). Penelitian Eijkman Institute memberi petunjuk bahwa gene pool penduduk Indonesia saat ini berasal dari Kepulauan Mentawai (Adi, 2006). Jika dikaitkan dengan teori persebaran 
manusia modern, maka pola migrasi di Indonesia banyak dipengaruhi oleh migrasi manusia modern melalui Jalur Selatan (Foster \& Matsumura, 2005; Macaulay et al., 2005; Thangaraj et al., 2005; Mellars, 2006) yang masuk Indonesia melalui arah Barat dan Utara.

Terkait dengan penyakit lepra, Monot et al., (2005) menyebutkan bahwa lepra tipe 1 ditemukan justru di jalur Selatan (sepanjang pantai di Timur Tengah, India, Srilanka, Thailand menuju ke Indonesia). Pendapat ini diperkuat dengan hasil penelitian Gwen et al. (2009) terhadap specimen berusia 2000 tahun dari India yang terinfeksi lepra dan juga penelitian Tayles \& Buckley (2004) di situs Noen U-Loke di Thailand dengan antikuitas masa logam (2500-1700 BP) yang juga terinfeksi lepra. Meletakkan LLI/5 dalam pola persebaran ini akan memperkuat arah persebaran lepra dan memberi petunjuk baru tentang sejarah penghunian Indonesia purba.

Menyadari bahwa sampel penelitian ini hanya satu specimen, maka harus sangat hati-hati dalam menarik kesimpulan tentang penghunian Indonesia berdasarkan prevalensi lepra. Dibutuhkan data lebih banyak dan metode lebih akurat sebagai bahan analisis yang lebih mendalam. Sekalipun demikian adanya bukti terinfeksinya LLI/5 oleh M.leprae adalah suatu tantangan baru dan sekaligus suatu petunjuk baru untuk menambah ketajaman analisis dan memperluas wawasan mengenai sejarah penghunian Indonesia.

\section{KESIMPULAN}

Identifikasi LLI/5 yang terinfeksi lepra dapat memberi petunjuk baru mengenai sejarah penghunian Indonesia. Berdasarkan hasil pemetaan prevalensi lepra pada rangka arkeologis dari penelitian-penelitian yang pernah dilakukan, memberi petunjuk bahwa munculnya lepra di Indonesia (Pulau Lembata) berkaitan dengan persebaran manusia modern. Bukti-bukti genetis dan morfologis dari penelitian-penelitian yang pernah dilakukan, memberi kontribusi pemikiran mengenai aktifitas interaksi penduduk Lembata dengan penduduk dari pulau-pulau lain sekitar Lembata. Dengan kata lain bahwa ada interaksi dari populasi migrant dan populasi local yang diduga adalah sebagai modus persebaran infeksi M.leprae. $M$. leprae ini terus terbawa penduduk melalui mobilitas (migrasi) mereka dari satu tempat ke tempat yang lain. Berdasarkan hal ini dapat pula dibangun suatu dugaan bahwa $M$. leprae bisa juga menjangkiti penduduk pulau-pulau lain yang pernah berinteraksi dengan penduduk Lembata atau penduduk migrant lain yang sudah terinfeksi $M$. leprae. Namun hal ini memerlukan lebih banyak bukti baik dari sisi jumlah sampel maupun metode. Di sisi lain, hal ini adalah tantangan baru penelitian-penelitian bidang paleomikrobiologi yang bersifat multidisipilin. 


\section{Ucapan terimakasih}

Penulis berterimakasih kepada Kepala Departemen Anatomi dan Histologi, FK Unair yang telah memberikan keluasan dan keleluasaan untuk meneliti koleksi Antropologi Ragawi. Penulis juga berterimakasih kepada Kelompok Studi Lepra di Lembaga Penyakit Tropis Unair yang telah memberi kesempatan bekerjasama meneliti lepra dari sisi molekuler. Terimakasih pula kepada D.B. Murti yang telah memberikan koleksi foto untuk memberikan gambaran lebih utuh dalam tulisan ini. Terutama, peneliti berterimakasih kepada Pater Jan yang sudah memberikan informasi luar biasa tentang situasi lepra di Pulau Lembata, umumnya dan Lewoleba, khususnya.

\section{KEPUSTAKAAN}

Adi, I,G.G.H. 2006 Gen yang berkisah. National Geographic, edisi Indonesia, Maret: $48-51$.

Adriaty, D., Wahyuni, R., Iswahyudi, Agusni, I., Izumi, S. 2010 TTC repeats variation of mycobacterium leprae isolates for analysis of leprosy endemic area in East Java, Indonesia. Indonesian Joumal of Tropical and Infectious Disease. Vol. 1(1): 38-41

Adriaty, D., Wahyuni, R., Iswahyudi, Aksono, B., Koesbardiati, T., Agusni, I., Izumi, S. 2011 DNA mycobacterium leprae pada tulang manusia purba dari Flores. Dipresentasikan pada KONAS XIII PERDOSKI di Manado.

Aufderheide, A.C. \& Rodriguez-Martin, C. 1998 The Cambridge Encyclopedia of Human Paleopathology. Cambridge University Press.

Atmosudiro, S. 1994 Gerabah Prasejarah di Liang Bua, Melolo dan Lewoleba: Tinjauan teknologi dan fungsinya. Disertasi. Yogyakarta: Universitas Gadjah Mada. Tidak diterbitkan.

Cann, L.R., Stoneking, M., \& Wilson, A.C. 1987 Mitochondrial DNA and Human Evolution. Nature 235: 31-36

Chhem, R.K \& Brothwell, D.R. 2008 Paleoradiology. Berlin: Springer Verlag

Foley, R. \& Lahr, M.M. 1997 Mode 3 technologies and the evolution of modern humans. Cambridge Archaeological Joumal 7(1):3-36 
Foster, P., \& Matsumura, S. 2005 Did early humans go North or South? Science Vol. 308: 965-966.

Glinka, J. 1978 Gestalt und Herkunft: Beitrag zur Anthropologischen Gliderung Indonesiens. Studia Instituti Anthropos Vol. 35. Bonn:Verlag des Anthropos-Instituts

Gwen, R., Tripathy, M., Misra, V.N., Mohanty, R.K., Shinde, V.S., Gray, K.M., Shug, M.D. 2009 Ancient Skeletal Evidence for Leprosy in India (2000 BC). PLOS ONE Vol. 4(5): 1-8

Haas, C.J., Zink, A., Palfi, G., Szeimies, U., Nerlich, A.G. 2000 Detection of Leprosy in ancient human skeletal remains by molecular identification of Mycobacterium leprae. Am.J.Clin Pathol 114:428436.

Jacob, T. 1967 Some problems pertaining to the racial history of the Indonesian region. Utrecht: Drukkerij Nerlandia

Koesbardiati, T. 2000 On the relevance of the regional continuity features of the face in East Asia. Disertasi. Universitaet Hamburg. Tidak dipublikasikan.

Koesbardiati, T., \& Suriyanto, R. 2007a Australomelanesoid in Indonesia: a Swinging-like movement. J.Anat Ind. Vol. 2 (1): 23-28

Koesbardiati, T., \& Suriyanto, R. 2007b Menelusuri jejak populasi morfologi pangur gigi-geligi: kajian pendahuluan atas sampel gigi-geligi dari beberapa situs purbakala di Jawa, Bali dan Nusa Tenggara Timur. Humaniora 19: $33-42$.

Lie, G.L. 1964 Beberapa Hasil Paleoanthropologis dari PenemuanPenemuan di Pantai Lewoleba, P. Lomblen. Madjalah Research Kedokteran Surabaja. 3: 121-137

Lie, G.L. 1965 Palaeonthropological results of the excavation at the coast of Lewoleba (Isle Lomblen). Anthropos 60:610-624

Louisiana Office of Public Health. 2004 Hansen Disease.

Macaulay, V., Hill, C., Achilli, A., Rengo., C., Clarke, D., Meehan, W., Blackbum, J., Semino, O., Scozzan, R., Cruciani, F., Taha, A., Shaari, N.K., Raja, J.M., Ismail, Z.Z., Goodwin, W., Bulbeck, D., Bandelt, H.J., Oppenheimer, S., Toroni, A., Richards, M. 2005 Single, rapid coastal settlement of Asia revealed by analysis of complete mitochondrial genomes. Science Vol. 308:1034-1036 
Matsuoka, M., Zhang, L., Budiawan, T., Saeki, K., Izumi, S. 2004 Genotyping of mycrobacterium leprae on the basis of the polymorphism of TTC repeats for analysis of leprosy transmission. Journal of Clinical Microbiology Vol. 42(2): 741-745

Mellars, P. 2006 Going East: New Genetic and Archaeological Perspectives on the Modern Human Colonization of Euroasia. Science Vol. 313:796-800.

Monot, M., Honore N., Gamier, T., Araoz, R., Coppee, Y-J., Celine, L., Sow, S., Spencer, J.S., Truman, R.W., Williams, D.L., Gelber, R., Virmond, M., Flageul, B., Cho, S.N., Ji. B., Oaniz-Mondolfi, A., Convit, J., Young, S., Fine, P.E., Rasolofo, V., Brennan, J., Cole, S.T. 2005 On the origin of leprosy. Science Vol. 308:1040-1042.

Monot, M., Honore, N., Garnier, T., Zidane, N., Sherafi, D., PAniz-Mondolfi, A., Matsuoka, M., Taylor, M.G., Donoghue, H.D., Bouwman, A., Mays, S., Watson, C., Lockwood, D., Khamesipour, A., Dowlati, Y., Jianping, S., Rea, T.H., Vera-Cabera, L., Stefani, M.M., Banu, S., MacDonald, M., Sapkota, B.R., Spencer, J., Thomas, Je., Harsman, K., Singh, P., Buso, P., Gattiker, A., Rougemont, J., Brennan, P., Cole, S.T. 2009 Comparative Genomic and phylogeographyc analysis of Mycobacterium Leprae. Nature Genetics 41, 1282-1289.

Ortner, D. J. 2003 Identification of Pathological Conditions in Human Skeletal Remains. Amsterdam: Academic Press.

Stringer, C. 1992 Replacement, continuity and the origin of Homo sapiens. Continuity or replacement: controversies in Homo sapiens (Brauer \& Smith, eds.). Rotterdam: A.A. Balkema

Stoneking, M. \& Cann, R. 1989 African origin of human mitochondrial DNA. The human revolution: behavioral and biological perspectives on the origins of modern humans (Mellars \& Stringer, Eds). Edinburg University Press.

Suzuki, K., Takigawa, W., Tanigawa, K., Nakamura, K., Ishido, Y., Kawashima, A., Wu, H., Akama, T., Sue, M., Yoshihara, A., Mon, S., Ishii, N. 2010 Detection of Mycobatrium leprae DNA from archaeological skeletal remains in Japan using whole genome amplification and polymerase chain reaction. PLOS ONE Vol. 5(8):1-8

Tayles, N. \& Buckley, H.R., 2004 Leprosy and Tuberculosis in Iron Age Southeast Asia? Am.J.Phys. Anthropol. 125:239-256 
Taylor, M.G., Widison, S., Brown, I.N., Young, D., Molleson, T. 2002 A Medieval case of lepromatous leprosy from $13-14^{\text {th }}$ century Orkney, Scottland. Joumal of Archaeological Science Vol 27(12): 1133-1138

Thangaraj, K., Chaubey, G., Kivisild, T., Reddy, A.G., Singh, V.K., Rasalkar, A.A., Singh, L. 2005 Reconstructing the origin of Andaman Islanders. Science Vol. 308: 996 